\title{
Pengaruh Kualitas Pelayanan Terhadap Kepuasan Pelanggan Transportasi Online GrabBike Pada Mahasiswa Fakultas Ilmu Sosial Dan Politik Universitas Sam Ratulangi
}

\author{
Reinhard K. Soromi \\ F. A. O. Pelleng \\ J. A. F. Kalangi \\ Jurusan Ilmu Administrasi Program Studi Administrasi Bisnis Fakultas \\ Ilmu Sosial dan Ilmu Politik Universitas Sam Ratulangi Manando \\ kevinsoromi23@gmail.com
}

\begin{abstract}
.
The purpose of this study was to determine the effect of service quality on customer satisfaction using GrabBike online transportation services to students of the Sam Ratulangi University Faculty of Social and Political Sciences. This type of research is quantitative descriptive. The relationship between quality of service and costumer satisfactions assists the costumer in revising its perception of service quality. Data Validity Test Results obtained all statement items declared valid. Data reliability test results of data obtained are stated that the data is reliable. The results of simple linear regression cost value more then the regression coefficient so that the regression coefficient is positive. The results of hypothesis test based on the significance value of the Coefficients table obtained significance, so that it can be concluded that the service quality variable affects the variable customer satisfaction. The test results of the coefficient of determination Adjusted $\boldsymbol{R}$ Square value which states the variable customer satisfaction is influenced by service quality variables, while the remaining is influenced by other variables that are not in this study. hence the correlation coefficient, which is included in the strong category so that there is a strong relationship between the quality of service to customer satisfaction and online GrabBike transportation to students of the Faculty of Social and Political Sciences, Sam Ratulangi University.
\end{abstract}

Keywords: Service Quality, Customer Satisfaction

\section{Pendahuluan}

Grab merupakan aplikasi interaktif di beberapa negara di asia tenggara, yang dapat digunakan dengan mudah via smartphone yang menjadi mediasi untuk mempertemukan kebutuhan penumpang sebagai pengguna jasa dengan supir dan mobil/motor sebagai penyedia jasa transportasi. Adapun cara pembayarannya menggunakan sistem tunai dan GrabPay. Saat ini grab menjadi solusi utama dalam pengiriman barang, dan bepergian ketika macet. Berkiprah di kota Manado lebih kurang 2 tahun. Konsumen merasa lebih mudah dan cepat memakai Grab dengan harga yang terjangkau dan promo-promo yang diberikan perusahaan. Sehingga dalam penelitian ini peneliti hanya terfokus 
pada jasa layanan GrabBike karena pada layanan GrabBike pelanggan dapat merasakan layanan mulai dari pemesanan hingga sampai ke tempat tujuan dengan cepat dan aman serta dapat menghindari kemacetan.

\section{Umumnya costumer yang} menggunakan GrabBike ini sendiri adalah anak muda atau remaja dengan kisaran umur 15 tahun sampai dengan 40 tahun karena mereka yang dinilai lebih cepat paham akan perkembangan zaman dan lebih bisa cepat menyesuaikan diri dengan hal-hal baru. Terutama costumer di daerah kampus atau universitas yang sering sekali menggunakan jasa transportasi online. Maka dari itu peneliti ingin menetapkan bahwa lokasi dan objek penelitian yang akan di teliti adalah mahasiswa di kawasan Universitas Sam Ratulangi terkhususnya mahasiswa di Fakultas Ilmu Sosial dan Politik. Sejauh ini pelanggan yang menggunakan jasa GrabBike di kota Manado khususnya pada kawasan Universitas Sam Ratulangi cukup banyak, walaupun terbilang adanya transportasi online lainnya tetapi cukup banyak masyarakat ataupun mahasiswa di kota Manado minat dan tetap menggunakan jasa ojek Grab walaupun tidak dalam penggunaan rutin.

Dalam hal ini kualitas pelayanan yang dilakukan oleh Grab masih belum mencapai tujuan yang diinginkan dan masih memiliki kelemahan yang membuat beberapa aspek dalam standar operasional Grab seperti diabaikan oleh driver itu sendiri, misalnya pembatalan secara sepihak dari driver tanpa mengkonfirmasi terlebih dahulu kepada pelanggan, serta ada driver yang merokok saat mengemudi sehingga menimbulkan kekhawatiran dari costumer dan ketidaknyamanan terhadap bau atau asap rokok tersebut bahkan ada yang ugal-ugalan saat mengemudi yang membuat pelanggan tidak merasa aman dan nyaman saat menggunakan jasa transportasi online, hal ini sangat berpengaruh terhadap kepuasan pelanggan dan menunjukkan bahwa masih adanya kelemahan-kelemahan driver dalam menyikapi kualitas pelayanan untuk memenuhi kepuasan pelanggan.

\section{Kualitas Pelayanan}

Menurut Kotler dalam Damayanti dkk (2018) kualitas adalah keseluruhan fitur dan sifat produk atau pelayanan yang berpengaruh pada kemampuannya untuk memuaskan kebutuhan yang dinyatakan atau tersirat. Sedangkan Menurut Kotler dalam Muliaty (2016) mendefinisikan pelayanan adalah setiap tindakan atau kegiatan yang dapat ditawarkan oleh suatu pihak kepada pihak lain, yang pada dasarnya tidak berwujud dan tidak mengakibatkan kepemilikan apapun. 
Menurut Kotler dalam Lestari (2016) Kualitas Pelayanan merupakan penilaian pelanggan atas keunggulan atau keistimewaan suatu produk atau layanan secara menyeluruh yang dimulai dari kebutuhan pelanggan dan berakhir pada persepsi pelanggan. Menurut Tjiptono dan Chandra dalam Ruben (2017) kualitas pelayanan mencerminkan perbandingan antara tingkat layanan yang disampaikan perusahaan dibandingkan ekspektasi pelanggan.

Indikator-indikator yang dapat digunakan untuk mengukur variabel kualitas pelayanan menurut Tjiptono dalam Panjaitan (2016) sebagai berikut :

1. Kehandalan : yakni kemampuan memberikan layanan yang dijanjikan dengan segera, akurat dan memuaskan Artinya para karyawan memberikan pelayanan yang sesuai dengan harapan pelanggan.

2. Daya tanggap yaitu keinginan para staf untuk membantu para pelanggan dan memberikan layanan dengan tanggap, yakni motivasi para karyawan dalam memecahkan masalah yang dihadapi pelanggan dalam menggunakan jasa

3. Jaminan yaitu mencakup pengetahuan, kompetensi, kesopanan dan sifat dapat dipercaya yang dimiliki para staf, bebas dari bahaya, risiko atau keraguan. Yaitu mengenai pengetahuan balk dari karyawan dalam menangani pertanyaan atau keluhan dari pelanggan

4. Perhatian meliputi kemudahan dalam menjalin relasi, komunikasi yang balk, perhatian pribadi, dan pemahaman atas kebutuhan individual para pelanggan yaitu sikap karyawan yang menunjukkan perhatian yang tulus dalam melayani pelanggan.

5. Bukti Fisik meliputi fasilitas fisik, perlengkapan, pegawai, dan sarana komunikasi.

\section{Kepuasan Pelanggan}

Menurut Zeithaml \& Bitner dalam Saidani (2012) mendefinisikan kepuasan pelanggan sebagai respon pelanggan terhadap evaluasi ketidaksesuaian yang dirasakan antara harapan dan kinerja aktual jasa. Menurut Kotler dan Keller dalam Panjaitan (2016) mengungkapkan kepuasan adalah perasaan senang atau kecewa seseorang yang berasal dari perbandingan antara kesannya terhadap kinerja (atau hasil) suatu produk dan harapan harapannya.

Menurut Day dalam Ruben (2017), menyatakan bahwa kepuasan atau ketidakpuasan pelanggan adalah respon pelanggan terhadap evaluasi ketidaksesuaian / diskonfirmasi yang dirasakan antara harapan sebelumnya (atau norma 
kinerja lainnya) dan kinerja aktual produk yang dirasakan setelah pemakaiannya.

Menurut Kotler dalam Wardani (2017) ada beberapa kriteria untuk mengukur kepuasan pelanggan adalah sebagai berikut:

a. Kesetiaan : Kesetiaan seseorang terhadap suatu layanan adalah repleksi dari hasil pelayanan yang memuaskan. Ukuran kepuasan dapat diukur kesetiaannya untuk selalu menggunakan produk/jasa tersebut.

b. Keluhan (komplain) Keluhan merupakan suatu keadaan dimana seseorang pelanggan merasa tidak puas dengan keaadaan yang diterima

c. dari hasil sebuah produk atau jasa tertentu sehingga dapat menimbulkan larinya pelanggan ketempat lain apabila keluhan ini tidak ditangani dengan segera.

d. Partisipasi: Pada dasarnya dapat diukur dari kesadarannya dalam memikul kewajiban menjalankan haknya sebagai pelanggan yang dimiliki dengan rasa tanggung jawab.

\section{Metode Penelitian}

Penelitian ini menggunakan pendekatan kuantitatif jenis deskriptif. Populasi dalam penelitian ini merupakan pengguna transportasi online grabbike mahasiswa Fakultas Ilmu Sosial dan
Politik, Universitas Sam Ratulangi yang jumlahnya tidak diketahui dan masuk dalam kategori populasi tak terhingga. Sampel yang digunakan dalam penelitian ini berjumlah 100 responden. Penentuan pengambilan sampel menggunakan non probability sampling dengan teknik purposive sampling. Teknik pengumpulan data menggunakan kuesioner, wawancara dan dokumentasi. Instrument penelitian ini menggunakan skala likert, uji instrument penelitian menggunakan uji validitas dan uji reliabilitas dan analisis data menggunakan analisis regresi linier sederhana.

\section{Hasil Penelitian}

\section{A. Uji Validitas Variabel Kualitas Pelayanan}

Berdasarkan hasil semua item pernyataan variabel kualitas pelayanan (X) yang diolah menggunakan SPSS for windows versi 25 dimana 20 item pernyataan menunjukan nilai $r_{\text {hitung }}$ lebih besar dari nilai $r_{\text {tabel }} 0,195$, sehingga disimpulkan bahwa uji validitas variabel kualitas pelayanan dinyatakan valid atau dapat dilanjutkan sebagai data penelitian.

\begin{tabular}{|c|c|c|c|}
\hline $\begin{array}{l}\text { Uji } \\
\text { Pelaı }\end{array}$ & $\begin{array}{l}\text { Validitas } \\
\text { nggan }\end{array}$ & Variabel & Kepuasan \\
\hline Pernyataan & R hitung & R tabel & Keterangan \\
\hline & 0,698 & 0.195 & Valid \\
\hline $\begin{array}{l}\text { P22 } \\
\text { P23 }\end{array}$ & $\begin{array}{l}0,744 \\
0,693\end{array}$ & $\begin{array}{l}0.195 \\
0.195\end{array}$ & $\begin{array}{l}\text { Valid } \\
\text { Valid }\end{array}$ \\
\hline
\end{tabular}




\begin{tabular}{cccc} 
P24 & 0,720 & 0.195 & Valid \\
P25 & 0,766 & 0.195 & Valid \\
P26 & 0.660 & 0.195 & Valid \\
\hline Sumber : Hasil olahan data, 2019 &
\end{tabular}

Sumber : Hasil olahan data, 2019

Berdasarkan tabel diatas semua item pernyataan variabel kepuasan pelanggan 6 item pernyataan menunjukan nilai $r_{\text {hitung }}$ lebih besar dari nilai $r_{\text {tabel }}$ sehingga dapat disimpulkan bahwa pada uji validitas variabel kepuasan pelanggan dinyatakan valid.

\section{Uji Reliabilitas Variabel}

\begin{tabular}{ccl}
\hline Variabel & $\begin{array}{c}\text { Cronbach } \\
\text { Alpha }\end{array}$ & Keterangan \\
\hline Kualitas Pelayanan & 0,752 & Reliable \\
Kepuasan Pelanggan & 0,779 & Reliable \\
\hline
\end{tabular}

Sumber : Hasil olahan data, 2019

Dapat dilihat nilai alpha cronbrach sebesar 0,752. Dari hasil tersebut instrument penelitian variabel menunjukan nilai $r_{\text {hitung }}$ lebih besar dari nilai $r_{\text {tabel }} 0,195$ sehingga instrument penelitian variabel kepuasan pelanggan dinyatakan reliabel.

\section{Analisis Regresi Linear Sederhana}

\begin{tabular}{|c|c|c|c|c|c|}
\hline & Coef & iicients & & & \\
\hline \multirow[b]{2}{*}{ Model } & \multicolumn{2}{|c|}{$\begin{array}{l}\text { Unstandardi } \\
\text { zed } \\
\text { Coefficients }\end{array}$} & \multirow{2}{*}{$\begin{array}{l}\text { Standa } \\
\text { rdized } \\
\text { Coeffi } \\
\text { cients } \\
\text { Beta }\end{array}$} & \multirow[b]{2}{*}{$\mathrm{t}$} & \multirow[b]{2}{*}{ Sig. } \\
\hline & B & $\begin{array}{l}\text { Std. } \\
\text { Error }\end{array}$ & & & \\
\hline $\begin{array}{ll}1 & \text { (Constan } \\
& \text { t) }\end{array}$ & 8.016 & 1.484 & & $\begin{array}{r}5.40 \\
2\end{array}$ & .000 \\
\hline $\begin{array}{l}\text { Kualitas } \\
\text { pelayana } \\
\text { n }\end{array}$ & .215 & .018 & .772 & $\begin{array}{r}12.0 \\
27\end{array}$ & .000 \\
\hline
\end{tabular}

a. Dependent Variable: kepuasan Pelanggan Sumber : Hasil olahan data, 2019

Kepuasan Pelanggan $=8,106+0,215 x$
Dari persamaan diatas dapat dijelaskan bahwa nilai kostanta sebesar 8,106 dimana mengandung arti bahwa nilai konsisten variabel kepuasan pelanggan adalah 8, 106. Kemudian koefisien regresi $\mathrm{X}$ sebesar 0,215 artinya kualitas pelayanan dari driver grabbike terhadap pelanggan ini baik atau terjadi penambahan pada variabel kualitas pelayanan maka kepuasan pada mahasiswa Fisip Universitas Sam Ratulangi akan meningkat sebesar 0,215. sehingga dapat dikatakan bahwa arah pengaruh variabel kualitas pelayanan terhadap kepuasan pelanggan adalah positif.

Diperoleh juga nilai signifikansi dari tabel Coefficients diperoleh nilai signifikansi sebesar $0,000<0,05$ sehingga dapat disimpulkan bahwa variabel kualitas pelayanan (X) berpengaruh terhadap variabel kepuasan pelanggan (Y). berdasarkan nilai $\mathrm{t}$ diketahui nilai $\mathrm{t}_{\text {hitung }}$ sebesar $12.027>t_{\text {tabel }} 1,984$ sehingga dapat disimpulkan bahwa variabel kualitas pelayanan berpengaruh terhadap variabel kepuasan pelanggan transportasi online grabbike pada mahasiswa Fakultas Ilmu Sosial dan Politik, Universitas Sam Ratulangi.

\section{E. Analisis Koefisien Korelasi dan Determinasi}

\begin{tabular}{|c|c|c|c|c|}
\hline \multicolumn{5}{|c|}{ Model Summary } \\
\hline Model & $\mathrm{R}$ & R Square & $\begin{array}{l}\text { Adjusted R } \\
\text { Square }\end{array}$ & $\begin{array}{l}\text { Std. Error of } \\
\text { the Estimate }\end{array}$ \\
\hline
\end{tabular}




\begin{tabular}{|c|c|c|c|c|}
\hline 1 & $.772^{\mathrm{a}}$ & .596 & .592 & 1.50518 \\
\hline
\end{tabular}

Sumber : Hasil olahan data, 2019

Diketahui nilai $\mathrm{R}$ Square sebesar 0,596 berarti 59,6\% yang menyatakan variabel kepuasan pelanggan dipengaruhi oleh variabel kualitas pelayanan $(\mathrm{X})$, sedangkan sisanya $40,4 \%$ adalah dipengaruhi oleh variable-variabel lain yang tidak terkandung atau tidak ada dalam penelitian ini .

\begin{tabular}{cc}
\hline Interval Koefisien & Tingkat Hubungan \\
\hline $0,00-0,199$ & Sangat Rendah \\
$0,20-0,399$ & Rendah \\
$0,40-0,599$ & Sedang \\
$0,60-0,799$ & Kuat \\
$0,80-1,000$ & Sangat Kuat \\
\hline
\end{tabular}

Sumber : Sugiyono, 2015

Diketahui juga koefisien korelasi $\mathrm{R}$ Square yang ditemukan sebesar 0,596 atau sebesar 59,6\% dimana termasuk pada kategori sedang sehingga terdapat hubungan yang sedang antara kualitas pelayanan terhadap kepuasan pelanggan transportasi online grabbike pada mahasiswa Fakultas Ilmu Sosial dan Politik, Universias Sam Ratulangi.

\section{Pembahasan}

Berdasarkan hasil penelitian yang diperoleh bahwa kualitas pelayanan berpengaruh terhadap kepuasan pelanggan, dalam hal ini Mahasiswa FISIP Unsrat merasakan adanya kepuasan meskipun tidak sedikit masalah yang ada, hal ini digambarkan dari beberapa contoh masalah yang ada seperti pembatalan secara sepihak dari driver tanpa mengkonfirmasi terlebih dahulu kepada pelanggan, serta ada driver yang merokok saat mengemudi sehingga menimbulkan kekhawatiran dari costumer dan ketidaknyamanan terhadap bau atau asap rokok tersebut bahkan ada yang berkendara ugal-ugalan saat mengemudi yang membuat pelanggan tidak merasa aman dan nyaman saat menggunakan jasa transportasi online, hal ini menyatakan bahwa masih minimnya pengetahuan standar oprasional dari driver Grab.

Berdasarkan dari hasil uji regresi sederhana yang menyatakan bahwa nilai kostanta yang didapat mengandung arti bahwa nilai variabel kepuasan pelanggan adalah konsisten. Kemudian koefisien regresi menyatakan bahwa nilai yang didapat adalah positif, sehingga dapat dikatakan bahwa arah pengaruh variabel kualitas pelayanan terhadap kepuasan pelanggan adalah positif. Selanjutnya hasil dari Uji $\mathrm{T}$ nilai signifikansi dari tabel Coefficients diperoleh nilai signifikansi sehingga dapat disimpulkan bahwa variabel kualitas pelayanan berpengaruh terhadap variabel kepuasan pelanggan.

Berdasarkan pada penelitian sebelumnya Panjaitan dkk 2016 memiliki kesamaan dengan hasil penelitian ini dimana penelitian sebelumnya menunjukan 
bahwa variabel kualitas pelayanan yang terdiri dari kehandalan, daya tanggap, jaminan, empati, dan bukti fisik berpengaruh terhadap kepuasan pelanggan pada JNE Cabang Bandung.

Dan memiliki kesamaan juga dengan hasil penelitian dari Rifaldi (2016) yang menyatakan bahwa setiap nilai angka pada kualitas pelayanan berpengaruh positif terhadap kepuasan pelanggan Transportasi Online Gojek Mahasiswa Administrasi Niaga Politeknik Negeri Jakarta.

Hasil penelitian ini diperkuat dengan penelitian sebelumnya dan juga diperkuat oleh teori menurut Sugiarto dalam Nasbir (2017) suatu kualitas disebut baik apabila penyedia jasa memberikan pelayanan yang melebihi harapan pelanggan. Kualitas tersebut dinilai baik apabila penyedia jasa memberikan pelayanan serta harapan pelanggan, jika pelanggan mendapatkan pelayanan lebih rendah dari harapannya maka kualitas pelayanan tersebut dinilai jelek, pencapaian kepuasan pelanggan memerlukan keseimbangan antara kebutuhan dan keinginan dan apa yang diberikan. Pihak driver grabbike telah memberikan kualitas pelayanan yang baik kepada pelanggan sehingga para mahasiswa Fakultas Ilmu Sosial dan Politik Universitas Sam Ratulangi merasakan kepuasan yang sesuai dengan harapan mereka. Dengan demikian bahwa semakin baik pemahaman pada kualitas pelayanan maka tujuan kepuasan pelanggan akan semakin efektif. Hal tersebut disebabkan karena konsep pemahaman pada kualitas tersebut disesuaikan dengan kemauan pelanggan, dengan adanya pemahaman pada pelanggan dan mengetahui apa yang sedang dihadapi permasalahan oleh pelanggan maka pelanggan akan merasa senang dengan layanan yang diberikan oleh driver GrabBike.

Selanjutnya hasil dari Uji Koefisien Determinasi yang menyatakan variabel kepuasan pelanggan dipengaruhi oleh variabel kualitas pelayanan, sedangkan sisanya dipengaruhi oleh variabel lain yang tidak ada dalam penelitian ini. Maka koefisien korelasi yang ditemukan dimana termasuk pada kategori sedang dilihat pada interpretasi koefisien korelasi menurut Sugiyono 2015 terdapat hubungan yang sedang antara kualitas pelayanan terhadap kepuasan pelanggan transportasi online grabbike pada mahasiswa Fakultas Ilmu Sosial dan Politik, Universitas Sam Ratulangi.

\section{Kesimpulan}

Berdasarkan hasil penelitian dapat disimpulkan bahwa hasil penelitian menunjukan adanya pengaruh positif antara kualitas pelayanan yang diberikan driver Grabbike dengan kepuasan 
pelanggan yang diterima Mahasiswa FISIP Unsrat, Sulawesi Utara, hal ini sudah terlaksana dengan baik dalam memberikan pelayanan kepada konsumen khususnya Mahasiswa Fakultas Ilmu Sosial dan Politik, Universitas Sam Ratulangi Manado dimana hasil penelitian menunjukan bahwa mahasiswa merasa puas terhadap pelayanan yang diberikan Driver Grabbike.

Hasil penelitian berdasarkan persamaan regresi sederhana bahwa nilai kostanta dimana mengandung arti bahwa nilai variabel kepuasan pelanggan adalah konsisten. Kemudian koefisien regresi menyatakan bahwa koefisien regresi tersebut bernilai positif artinya kualitas pelayanan berhubungan positif dengan kepuasan pelanggan mahasiswa Fakultas Sosial dan Politik Universitas Sam Ratulangi, maka dapat dikatakan bahwa arah pengaruh variabel kualitas pelayanan terhadap kepuasan pelanggan adalah positif. Kemudian hasil nilai Adjusted $\mathrm{R}$ Square menyatakan variabel kepuasan pelanggan dipengaruhi oleh variabel kualitas pelayanan, sedangkan sisanya adalah dipengaruhi oleh variabel lain yang tidak ada dalam penelitian ini.

\section{Saran}

Berdasarkan hasil penelitian maka penulis memberikan saran-saran yaitu: dengan adanya hasil penelitian ini bahwa arah pengaruh variabel kualitas pelayanan terhadap kepuasan pelanggan adalah positif maka para driver grabbike perlu mempertahankan mutu dan kualitas pelayanan yang juga dapat berdampak baik bagi kemajuan perusahaan. Kemudian hasil yang diperoleh besarnya pengaruh kualitas pelayanan driver grabbike terhadap kepuasan pelanggan pada mahasiswa, maka pihak driver grabbike harus meningkatkan lagi kualitas pelayanannya seperti selalu memberikan rasa nyaman dan aman terhadap pelanggan, mengikuti prosedur pelayanan jasa transportasi sesuai standar ketentuan dan ketepatan yang sesuai dengan perundang-undangan yang berlaku yaitu peraturan Menteri Perhubungan Nomor 26 tahun 2017 tentang penyelenggaraan Angkutan Orang dengan Kendaraan Bermotor Umum Tidak Dalam Trayek (PM 26).

\section{Daftar Putsaka}

Muliaty. 2016. Faktor-Faktor Yang Mempengaruhi Kualitas Pelayanan Pada Politeknik Negeri Media Kreatif Makassar. Jurnal Administrasi Publik. 6(1) : 76-82

Damayanti E dan Rosyad U. 2018. Pengaruh Kualitas Pelayanan Transportasi Ojek Online Grab Terhadap Kepuasan Pelanggan Menggunakan Grabbike. Jurnal Manajemen Komunikasi. 2 (1) : 600603. 
Lestari. S. 2017. Pengaruh Kualitas Pelayanan Terhadap Kepuasan Pelanggan Pada Instalasi Farmasi Rumah Sakit Islam Siti Khadijah Palembang. Skripsi. Fakultas Ekonomi dan Bisnis Islam UIN Raden Fatah.

Panjaitan, J. E. dan Yuliati, A.L. 2016. Pengaruh Kualitas Pelayanan Terhadap Kepuasan Pelanggan Pada JNE Cabang Bandung. Derema Jurnal Manajemen. 11(2) : 265-289.

Ruben, E.S.P. 2017. Pengaruh Kualitas Pelayanan Terhadap Kepuasan Konsumen Pada Restoran Saung Citra Bandar Lampung. Skripsi. Fakultas Ekonomi dan Bisnis, Universitas Bandar Lampung : 1-63.

Wardani, T. 2017. Pengaruh Kualitas Pelayanan Terhadap Kepuasan Konsumen Pada Bisnis Jasa Transportasi Gojek Studi kasus Mahasiswa FEB UIN Sumatera Utara. 